\title{
A Comparative Study of Metaphors in Fairy Tales in English and Japanese
}

\author{
REN IMAI \\ $\mathrm{PhD}$ student in Cultural Linguistics at Eötvös Loránd University
}

\begin{abstract}
The purpose of this study is to compare metaphors of English and Japanese fairy tales. In the paper, I reveal differences of conceptualisation between tales of the two languages and cultures. I analysed two traditional tales, an English fairy tale Jack and the Beanstalk and a Japanese one Momotaro 'The Peach Boy', which may be influenced by different cultural concepts. I found conceptual metaphors in each tale and examined them through universal or cultural categorisation. Some of the conceptual metaphors I found are the same in the two fairy tales, even if they are effected by very different cultures. On the other hand, due to the differences of their cultures, we can also find culturally dissimilar conceptual metaphors in the tales. I discussed why there are differences between cultural metaphors. They show us a different view influenced by the culturally different aspects between the two languages.
\end{abstract}

Keywords: metaphors, comparative study, fairy tales, Japanese culture, translation

Fairy tales, like all language products, reflect the conceptualisation of the world according to a particular culture. When children read books, they learn not only the language but also the view of the world. Seen in this light, children's stories play an important role in teaching readers about our world (Okamoto, 1990). Fairy tales are written for a young audience who are initiated into a particular culture through children's stories as well. Children who grow up in different cultures learn dissimilar views of the world. Fairy tales written in English and Japanese are expected to reflect the differences and similarities between the conceptualisation of reality.

The purpose of this study is to compare English and Japanese fairy tales and to find similarities or differences between the two cultures. Then, I will investigate the influence of traditional tales on their readers from the standpoint of Cognitive Linguistics. The questions I aim to answer in this paper are as follows: (1) What kind of views do tales give readers about the real world?; (2) Are there any differences in conceptualisation between tales in different languages? I will analyse universal and cultural metaphors in fairy tales written in the two languages. Because of their familiarity and popularity, I selected the English fairy tale Jack and the Beanstalk and the Japanese tale Momotaro 'The Peach Boy'.

\section{Theoretical Background}

Lakoff E Johnson (1980) showed that our thought processes are largely metaphorical, and metaphors are pervasive in everyday language. When a speaker says we aren't going anywhere, the expression go somewhere indicates travelling to a destination, and the word we implies the travellers. However, when we hear this sentence in a suitable context, we can interpret that the speaker does not think about journey but about love. Here we map the destination of the journey to the goal of the relationship, and the travellers to the lovers in our mind. This is a way of thinking about love, an abstract concept. We can understand an abstract concept (LOVE) well if we use a concrete concept (JOURNEY) and if the abstract concept (LOVE) corresponds to the concrete concept (JOURNEY). According to Kövecses (2010), metaphorical sentences such as we aren't going anywhere are called metaphorical linguistic expressions. Metaphorical linguistic expressions are, in a word, ways of 
talking. On the other hand, understanding LOVE, that is, one conceptual domain in terms of another conceptual domain such as JOURNEY, is usually given by the means of the formula: "CONCEPTUAL DOMAIN A IS CONCEPTUAL DOMAIN B” (Kövecses, 2010. 4.) written in small capital letters. The relationship between conceptual metaphors and metaphorical linguistic expressions is the following: "the linguistic expressions (i.e., ways of talking) make explicit, or are manifestations of, the conceptual metaphors (i.e., ways of thinking)" (Kövecses, 2010. 7.).

The sentence I'm feeling up today is another example of metaphorical linguistic expressions, and HAPPY IS UP is one of the conceptual metaphors (Kövecses, 2010). A conceptual metaphor consists of physical source domains and abstract target domains, and the target domains are understood by the source domains. Thus, in the abovementioned example, the conceptualisers understand the abstract emotion of happiness through basic human spatial orientation which is upward oriented. The conceptualisation in the example is based on human experiences, for instance, that we are jumping when we are very happy, or happiness makes us warm as our body temperature increases. These are common experiences of human beings; therefore, it is possible that conceptual metaphors which are based on human bodily experiences are universal (Kövecses, 2010). We can say that these are universal conceptual metaphors, which are a type of conceptual metaphors.

On the other hand, there are also cultural conceptual metaphors, which depend on the conceptual system of a language. According to Velasco-Sacristán \& Fuertes-Olivera (2006), the definition of cultural metaphors is the following: "cultural metaphors are those that reflect sociopolitical values not necessarily present in all cultures" (Velasco-Sacristán E Fuertes-Olivera, 2006. 1993.). My hypothesis is that fairy tales involve the use of conceptual metaphors in both in English and Japanese. We can find universal conceptual metaphors even if they are affected by very different cultures. However, due to the differences of cultures, there are also culturally dissimilar conceptual metaphors in them. The cultural metaphors of tales may influence readers in how they should behave well in their cultures. Fairy tales may teach readers what an appropriate attitude in their society is.

All in all, we are used to talk and think metaphorically, and our metaphorical thinking contains universal conceptual metaphors and cultural conceptual metaphors. Universal metaphors are based on human bodily experiences, and thus they may be similar among different languages. Cultural metaphors are, in contrast, influenced by our culture, and thus they may vary depending on languages. If I want to prove whether there are any differences in conceptualisation between tales in different languages, I will need to find universal and/or cultural metaphors in the tales of the English and Japanese languages. Then, I will analyse why there are differences between these cultural metaphors and discuss how they influence the readers of tales.

\section{Method}

For this study, I selected an English fairy tale, Jack and the Beanstalk and a Japanese one, Momotaro 'The Peach Boy'1. The former, Jack and the Beanstalk, was published as The Story of Jack Spriggins and the Enchanted Bean in 1734 and was rewritten by Joseph Jacobs in English Fairy Tales in 1890. The Japanese fairy tale, Momotaro 'The Peach Boy' is one of the five most famous Japanese fairy tales. It is not known exactly when it first appeared, but several scholars say that it appeared during the Muromachi period (a division of Japanese history running from approximately 1336 to 1573) and spread in the Edo period (between 1603 and 1868). Sazanami Iwaya collected the fairy tale as Nihon mukashi banashi 'Japanese folk tales' in 1894. In what follows, I

\footnotetext{
1 In Hungarian the book was published as: Vihar Judit (2001, szerk.) Momotaró, a barackfiú. Alfabéta, Budapest..
} 
A Comparative Study of Metaphors in Fairy Tales in English and Japanese

will summarise only the story of Momotaro 'The Peach Boy'. Once upon a time, an old couple lived in a small village. One day the old man went to the mountain to gather firewood and the old woman went to the river to wash clothes. While she was washing the clothes, she saw a giant peach up the river. From the peach, a boy was born, and he was named "Momotaro". He went to Devil's Island to conquer the bad devils with some millet dumplings, which the old couple made. On the way to Devil's Island, a dog, a monkey and a pheasant asked Momotaro to give each of them one dumpling for the service of following him. When they arrived at the Island after a long journey, they ate the dumplings and became strong. They fought, and the devils were defeated. Momotaro returned safely to the village with the devils' treasures, so the old couple and the village people were very happy. From that day on, Momotaro and the old couple lived happily ever after.

I found conceptual metaphors in each tale and I examined them to decide which ones are universal and which ones are cultural. I will present in the below section three important points: the GOOD IS UP metaphor and RESOURCES ARE FOOD metaphor as universal metaphors, and the concept of SOCIETY which shows cultural differences.

\section{Analysis and Discussion}

\section{Universal Metaphors}

Let us begin with the GOOD IS UP metaphor. This is a universal metaphor (see Kövecses, 2010), and I found it in both the English and the Japanese tales. In Momotaro 'The Peach Boy', we may take "she (the old woman) saw a giant peach coming from up the river" (Nakayama, 1989) as an example. The good thing, represented by the peach, that will be a delicious treat for the old couple and that will give birth to a baby boy (Momotaro), is coming from the upper reaches of the river, which are up. In Jack and the Beanstalk, "a big beanstalk went up and up and up till it reached the sky" (Joseph, 1890), and the story itself means
GOOD IS UP because Jack found treasures up in the sky. Going up means waiting for miracle and hope.

The second point is the RESOURCES ARE FOOD metaphor (mentioned in Kövecses, 2010. 67.). In Momotaro 'The Peach Boy', Momotaro told the old couple, "please make me some millet dumplings" (Nakayama, 1989) to prepare for conquering the bad devils. Another example is "If he eats one, he will have the power of one hundred men. If he eats two, he will have the power of two hundred men" (Nakayama, 1989). We can consider that there is the RESOURCES ARE FOOD metaphor behind these expressions.

Although the same conceptual metaphor can be found in the above-mentioned examples in both languages, there is also a difference: the Japanese tale has a positive view, whereas the English tale has a negative view. I may claim that it is a cultural difference on the grounds that they show the same metaphor in different ways. There is an example in $\mathrm{Mo}$ motaro 'The Peach Boy', "Let's put our hearts into these dumplings" (Nakayama, 1989). In the background of this linguistic metaphorical expression there is the conceptual metaphor BODY IS A CONTAINER FOR THE EMOTIONS, furthermore, food is also a container for love. We may consider that it is also a conceptual metaphor, LOVE IS FOOD. If the readers can understand this metaphor, it is possible that they can understand expressions such as I am starved for love when they come across them for the first time.

It is interesting that the role of food in the two stories is different. In Momotaro 'The Peach Boy', food such as peach and millet dumplings are there to be eaten, however, in Jack and the Beanstalk, food such as beans and hen exist not for being eaten but for magic or wealth. The Momotaro 'The Peach Boy' tale also shows that food has power in society. The reason why the animals went with Momotaro to Devil's Island was that he gave them the dumplings.

All in all, I have found that there are universal metaphors in English and Japanese fairy tales. However, even when there are the 
same universal metaphors behind linguistic metaphorical expressions, they show us a different view influenced by the culturally different aspects between the two languages. That is, there are differences of conceptualisation of the world between fairy tales of different languages.

\section{Cultural Metaphors}

The third point is the concept of SOCIETY. In his study, Kövecses (2015) mentions that there are different societies where the notion of the SELF goes together with a different network of concepts between English and Japanese, that is individualistic and collectivistic society. We can also find these differences in fairy tales.

Collectivistic society is described by Kövecses in the following way: "In such a society, the self will view himself or herself as interdependent on each other," and "The self cooperates with others in the group in order to promote the well-being of members of the group and that of the group" (Kövecses, 2015. 64.). In Momotaro 'The Peach Boy', Momotaro went to Devil's Island with animals such as a dog, a monkey and a pheasant, who he met along the way. Their opponents were the head devil and his companions. In this story, each character had his own role, for example, Momotaro picked up the devils and threw them, the dog bit them, the monkey scratched them and the pheasant pecked them. The characters knew what special skill they had and they cooperated with each other for the same goal. When the devils were defeated, the head devil apologised to Momotaro. This scene represents the microcosm of society where the leader should take responsibility. At the end of the story, not only the old couple but everybody in the village was happy because Momotaro returned safely with the treasures. Here we may see the cultural metaphor HAPPINESS IS TO LIVE IN PEACE TOGETHER.

In contrast to the society above, individualistic society is described by Kövecses in the following way: "In such a society, individual people will regard themselves as being inde- pendent of others, that is, as autonomous," and "Individual people will have their own unique personal goals and desires" (Kövecses, 2015. 63.). In Jack and the Beanstalk, Jack climbed up to the sky alone, and his opponent, the ogre, was alone as well. When Jack swapped his cow for the beans, when he decided to climb the beanstalk, and also when he climbed it again, there was only his desire. Taking the bag of gold, the golden hen and the golden harp were just Jack's desires. At the end of the story, Jack and his mother became very rich, he married a princess, and they lived happily ever after. HAPPINESS IS TO LIVE WITH WEALTH AND STATUS can be seen behind these.

Kövecses considers the metaphorical conceptualisation of the SELF as culture-specific, that is the concept of SELF varies in English, Hungarian and Japanese cultures. Kövecses (2015) explored the network of the concept associated with the self, then identified two antagonistic networks of concepts, based on which a society can be called individualistic or collectivistic. "The two sets of concepts can be brought into correspondence with each other in the following way: Independence (personal)-Interdependence; Self-centeredOther-centered; Self-expression-Saving the other's face; Self-indulgence-Self-denial; Personal goals and desires-Social goals and desires; Happiness (personal)-Happiness (social); Achievement (personal)-Achievement (social); Self-interest-Interest (social); Selfishness-Sharing; Suspicion-Trust; Pride-Humility; Competition-Cooperation; Indifference-Care, Concern" (Kövecses, 2015. 65.). Based on this characterization, I will now compare the English fairy tale with the Japanese one.

\section{a) Independence and Interdependence.}

Jack and his mother tried to survive by themselves when they did not know what they should do for a living: they were forced to sell their cow, rather than receiving help from their town. It shows that Jack regards himself as being independent of others. On the other hand, when devils came to Momo- 
taro's village and made trouble for the village people, Momotaro said he would go to conquer the bad devils because he was a member of his village. This shows that Momotaro views himself as interdependent on other people. Another scene also shows us this difference. Jack climbed alone up the beanstalk until it ended in the sky, while Momotaro had partners on the way.

\section{b) Self-indulgence and Self-denial.}

Jack climbed up to the sky again and again because of his interest or concern, he stole the ogre's treasure because he wanted it. This shows that Jack seeks pleasure. In contrast, Momotaro went to Devil's Island because he wanted to save his village, even if he put himself in danger. This shows that Momotaro is characterized by self-denial.

\section{c) Personal goals and desires and Social goals and desires.}

Jack took the bag of gold, the golden hen and the golden harp from the ogre because he wanted to try his luck at the top of the beanstalk, that is, he had his own desires. On the other hand, Momotaro and his friends cooperated with each other when conquering the devils, so it can be said that Momotaro's goal and desire was shared with others.

\section{d) Personal happiness and Social happi- ness.}

At the end of the stories, we can see further differences. Jack and his mother became very rich, he married a princess, and they lived happily ever after. This shows that Jack's main goal and desire was personal happiness. However, the major goal in the life of Momotaro was happiness for the whole group. When Momotaro returned safely with the treasures, not only the old couple but everybody in the village was happy.

\section{e) Personal achievement and Social achievement.}

For Jack and also for Momotaro, it is important that they achieve their own goals. However, the achievement of the better- ment of the entire society seems a primary objective in Momotaro's story. The story tells about the happiness of the old couple and the village people earlier than about Momotaro's, putting the main focus on the community, rather than on the main character.

\section{f) Self-interest and Social interest.}

Jack was driven by his own interest when he was in the sky and when he gave away a cow for a set of beans. His interest came before the interest of his mother, who wanted to sell the cow for money. In contrast, Momotaro's actions were motivated by the interests of the whole group: he went to Devil's Island for all of the village people.

\section{g) Selfishness and Sharing.}

In Jack's story, the gold of the ogre is a limited resource. The author of the story explains to the readers that they accomplish life goals at the expense of others. At the end of the story, the ogre lost his treasure and died. Momotaro had the attitude of sharing in his relations with the animals who helped him. In the end, the treasure of the devils was shared with the village people.

\section{h) Suspicion and Trust.}

Jack believed a funny-looking old man when he proposed to exchange his cow for some magical beans. Jack's mother got mad and taught him that he should not trust others. However, even if he swapped his cow for some beans, Jack was suspicious of the old man. The old man managed to trick Jack, but he did not succeed in earning his sincere trust. In Momotaro 'The Peach Boy', Momotaro trusted the animals, giving them dumplings when they wanted to eat.

\section{i) Pride and Humility.}

When Jack climbed down with the ogre's gold, he showed it to his mother and said: "Well, mother, wasn't I right about the beans. They are really magical, you see." (Joseph, 1890) He was proud. However, Momotaro's attitude after conquering the devils is not included in the story. 


\section{j) Competition and Cooperation.}

Momotaro cooperated with the animals in the group in order to promote the well-being of the members of the group and that of the group. Jack competed with the ogre over the possession of the ogre's wealth.

\section{k) Indifference and Care, Concern.}

When the ogre is defeated, it seems that he deserved his fate in Jack and the Beanstalk, and there is total indifference towards the fate of the ogre's wife. In Momotaro 'The Peach Boy', when the devils were defeated, the head devil apologised to Momotaro, who forgave the devils and let them live.

All in all, I could not find the following networks of Kövecses' (2015) concepts: Selfcentered; Other-centered; Self-expression; Saving the other's face. It is probable that research on other tales can cover this gap. However, we can say that "the contextual factor of ideology led to a difference in the salience of the concept of SELF" (Kövecses, 2015. 65.) in fairy tales as well. It is possible that these contents are present in fairy tales because adults want to give children the worldviews of their own cultures and societies through children's literature.

\section{Conclusion}

I would like to emphasise the point that these cultural metaphors have an influence on the conception of the world of readers. Children learn not only the grammar or the lexicon of their language but also the view of the world, and in this respect children's literature plays an important role in teaching them. Adults want to give readers their cultural point of view of the world through children's books.

From now on, a more pragmatic and sociolinguistic approach will be needed to strengthen my proposition, and the conceptu- alisation of SOCIETY in particular. When the devils were defeated and the head devil apologised to Momotaro, he used an apologising strategy: the leader of the devils handed over all their treasures in return for forgiveness. It is possible that the reason is that apologising is very important in Japanese society. On the other hand, even though the ogre did not do anything bad to Jack, he died simply because he was an ogre, who is regarded as an absolute evil. We may possibly consider that this is based on view of religion. Finally, in future research, I would like to compare fairy tales written in other languages such as Hungarian and Italian. It is likely that we can discover the small world view thanks to cultural metaphors, and they can teach us how we should behave in their culture.

\section{References}

Joseph, J. (1890) Jack and the Beanstalk. English Fairy Tales, 13. David Nutt, London, 59-67.

Kövecses, Z. (2010): Metaphor: A practical introduction (2nd ed.). Oxford University Press, Oxford.

Kövecses, Z. (2015): Where metaphors come from: Reconsidering context in metaphor. Oxford University Press, New York. https://doi.org/10.1093/acprof.oso/9780190224868.001.0001

Lakoff, G., \& Johnson, M. (1980): Metaphors We Live By. University of Chicago Press, Chicago.

Nakayama, K. (1989): Momotaro, the peach boy: Tanoshii eigo, meisaku dowwa 1. Gakken, Tokyo.

Okamoto, K. (1990): The image of children's books in Japanese and French: A study of Contrastive Linguistics. Kochi University Gakujutsu Kenkyu Hokoku, 39, 93-104.

Velasco-Sacristán, M. \& Fuertes-Olivera, P. A. (2006): Towards a critical cognitive pragmatic approach to gender metaphors in advertising English. Journal of Pragmatics, 38, 1982-2002.

https://doi.org/10.1016/j.pragma.2005.07.002

Ren Imai (2019): A Comparative Study of Metaphors in Fairy Tales in English and Japanese. Gyermeknevelés, 7. 1. sz., 77-82. 